\title{
VACUUM ASSISTED CLOSURE IN DIABETIC FOOT MANAGEMENT
}

Moganakannan $\mathrm{K}^{1}$, Prema $\mathrm{M}^{2}$, Arun Sundara Rajan A. R ${ }^{3}$

\section{HOW TO CITE THIS ARTICLE:}

Moganakannan K, Prema M, Arun Sundara Rajan A. R. "Vacuum Assisted Closure in Diabetic Foot Management". Journal of Evolution of Medical and Dental Sciences 2014; Vol. 3, Issue 52, October 13; Page: 12221-12224, DOI: $10.14260 /$ jemds/2014/3614

ABSTRACT: Comparision of vacuum assisted closure vs conventional dressing in management of diabetic foot patients. 30 patients were taken in that 15 underwent vacuum therapy and remaining 15 underwent conventional dressing.They were analysed by the development of granulation tissue and wound healing.The study showed Vac therapy is the best modality for management of diabetic foot patients.

KEYWORDS: Diabetic foot, vacuum assisted closure.

INTRODUCTION: India is the diabetic capital. One of the commonest complications of diabetes is soft tissue infection of the extremities especially the foot. Diabetic foot is the collective term for a wide range of infections of the foot. Diabetic foot accounts for significant morbidity.(1) It requires prolonged medical treatment and repeated surgical intervention in the form of debridement and replacement of tissue loss, vacuum assisted closure is an effective method of dressing that acts by reducing tissue edema, improving granulation tissue \& vascularity.(2) It significantly reduces wound healing time. We present our experience with 15 diabetic foot patients who were managed by vacuum assisted closure.(3)

AIM \& OBJECTIVES: to demonstrate the efficacy of vacuum assisted closure in diabetic foot ulcer over conventional dressing. ${ }^{(4)}$

MATERIALS \& METHODS: 30 patients with diabetic foot ulcer (wagners class) were selected for the study. 15 were randomly assigned to undergo vacuum assisted closure 15 received conventional dressing with betadine and saline gauze.(5) Time taken for granulation, duration of hospital stay, need for tissue replacement etc. were analyzed \& compared.(6)

INCLUSION CATERIA: Patients with diabetic foot infections above 18years of age.

\section{EXCLUSION CATERIA:}

1. Patients with previous $\mathrm{h} / \mathrm{o}$ of peripheral arterial disease or previous surgeries for arterial occlusive disease.

2. Patients with necrotizing fascitis and severe sepsis, previous amputations.

3. Patients with obvious clinical signs of vascular insufficiency or ischaemia including absent peripheral pulses.

4. Patients in renal failure or $\mathrm{h} / \mathrm{o}$ of poor compliance with medical treatment.

Conventional dressing patients underwent dressing everyday with beta dine and saline gauze. Vacuum dressing patients underwent dressing every 3rd day, suction have to be done every 6th hour. Vacuum assisted closure system unit was programmed to deliver controlled negative pressure up to 


\section{CASE REPORT}

$125 \mathrm{~m} / \mathrm{hg}$. Both the groups were followed for the development of granulation tissue and healing process.

Depth and size of the wound were inspected and recorded before and every three days during the study period. Types of diabetes mellitus and state of its control, duration of ulcer, wound location and frequency of underlying disease were evaluated for all the study patients. Depth of ulcers was measured by means of vernier caliper in the biggest vertical diameter of the ulcers and improvement of ulcer defined according to wagner scale.

RESULTS: Improvement of the wound in the form of reducing the diameter and depth and increasing proliferation of granulation tissue was significant in VAC group. Satisfaction of patients in the VAC group was evaluated as no amputation was done in this group. the average time taken for granulation was low (-days) in the vacuum group compared to conventional dressing which was statistically (not) significant. (7) Wagner score was reduced in both the study groups, although this decrement was not significant in conventional dressing group. We performed the wagner score for the study patients before and after the treatment. Mean analysis of wagner score showed that both the study groups, it was decreased although decrement was not significant in conventional group.

Evaluation of formation of granulation tissue showed that $70 \%$ and $50 \%$ of the study patients in VAC group and conventional dressing group. Had the formation of granulation tissue during the two weeks of treatment. All the patients in the VAC group were satisfied with their therapy procedure and its results, whereas 12 patients in the conventional group were not satisfied only three were satisfied. Due to consideration of major/minor amputation as final results of the present intervention, significant intervention was seen. No patients in VAC therapy underwent minor/major amputations, 14 were cured completely. In conventional dressing group 12 patients went for amputations and three were completely cured.

Discussion: diabetic ulcer of the foot is a cause of significant morbidity in diabetic patients. Ulcer is often the starting point for severe progressive soft tissue infection which may lead to amputation. Conventional management of diabetic foot comprises of repeated wound debridement, regular dressing and replacement of tissue loss.(8) Vacuum assisted closure is a new method of dressing which acts in multiple ways which facilitate rapid wound healing:

1. Reduces tissue \& wound edema.

2. Improves vascularity.

3. Removes debris effectively. ${ }^{(9)}$

Vacuum dressing is done by placing a foam sponge on the top of the ulcer with continuous or intermittent vacuum being applied on the top of the foam. The entire foam dressing has to be airtight for vacuum to be effective.(10) The vacuum dressing is changed once in 3 days for inspection of the wound and removal of necrotic tissue when necessary. Antibiotic are given based on culture sensitivity. In our experience vacuum dressing significantly reduced time to granulation and the area of ulcer requiring tissue replacement in the form of graft or flap was also reduced.(11) The complications associated with vacuum dressing was spread of osteomyelitis in one case.(12)

Vacuum assisted closure assists in wound closure by applying negative pressure to the surface and margins of the wound. The negative pressure therapy is applied to a special foam dressing cut to the dimensions of the wound and positioned in the wound cavity. The continuous negative pressure is very effective in removing exudate from the wound. 
Negative pressure promotes wound contraction to cover the defect and may trigger intra cellular signaling that increases cellular proliferation.

VAC therapy optimizes blood flow, decreases edema and aspirates accumulated fluid, thereby facilitating bacterial clearance. Our study showed size, depth and wagner class in VAC dressing were reduced significantly compared to conventional dressing. About $70 \%$ and $50 \%$ of VAC and conventional dressing groups had granulation tissue.

In the VAC group, the mean changes in the size of the ulcer were three weeks lesser than conventional group. The VAC therapy reduced the need for hospitalization and duration of stay. Although the number of patients in this study was limited the results obtained from this study and satisfaction of the patients allowed us to conclude that VAC is suitable treatment modality for diabetic foot patients.

CONCLUSION: Comparison of vacuum dressing vs conventional dressing in diabetic foot patients. 30 patients were taken in that 15 underwent vacuum dressing and remaining 15 underwent conventional dressing. Patients who underwent vacuum dressing took less time for developing granulation tissue. Vacuum assisted closure is an effective method of management of diabetic foot ulcers and it significantly reduces healing time and the area that needs tissue replacement.(13)The result obtained from the study showed VAC therapy is the suitable treatment modality for management of diabetic foot patients.

\section{REFERENCES:}

1. Fleischmann W, Strecker W, Bombelli M, Kinzl L. [Vacuum sealing as treatment of soft tissue damage in open fractures]. Unfallchirurg 1993; 96 (9): 488-92.

2. Fleischmann W, Lang E, Kinzl L. [Vacuum assisted wound closure after dermatofasciotomy of the lower extremity]. Unfallchirurg 1996; 99 (4): 283-7.

3. Fleischmann W, Lang E, Russ M. [Treatment of infection by vacuum sealing]. Unfallchirurg 1997; 100 (4): 301-4.

4. Muller G. [Vacuum dressing in septic wound treatment]. Langenbecks Arch Chir Suppl Kongressbd 1997; 114: 537-41.

5. Kovacs L, Kloppel M, Geishauser S, Schmiedl S, Biemer E. Vacuum sealing: a new and promising regimen in the therapy of radiation ulcers. Br J Surgery 1998; 85: 70.

6. Mullner T, Mrkonjic L, Kwasny O, Vecsei V. The use of negative pressure to promote the healing of tissue defects: a clinical trial using the vacuum sealing technique. Br J Plast Surg 1997; 50 (3): 194-9.

7. Banwell P, Withey S, Holten I. The use of negative pressure to promote healing. Br J Plast Surg 1998; 51 (1): 79.

8. Morykwas MJ, Argenta LC, Shelton-Brown EI, Mc Guirt W. Vacuum-assisted closure: a new method for wound control and treatment: animal studies and basic foundation. Ann Plast Surg 1997; 38 (6): 553-62.

9. Philbeck TE, Whittington KT, Millsap MH, Briones RB, Wight DG, Schroeder WJ. The clinical and cost effectiveness of externally applied negative pressure wound therapy in the treatment of wounds in home healthcare Medicare patients. Ostomy Wound Manage 1999; 45 (11): 41-50.

10. Collier. Know-how: A guide to vacuum-assisted closure (VAC). Nurs Times 1997; 93 (5): 32-3. 


\section{CASE REPORT}

11. Tang AT, Ohri SK, Haw MP. Novel application of vacuum assisted closure technique to the treatment of sternotomy wound infection. Eur J Cardiothorac Surg 2000; 17(4): 482-4.

12. Morykwas MJ, Argenta LC. Nonsurgical modalities to enhance healing and care of soft tissue wounds. J South Orthop Assoc 1997; 6 (4): 279-88.

13. Fabian TS, Kaufman HJ, Lett ED, Thomas JB, Rawl DK, Lewis PL, Summitt JB, Merryman JI, Schaeffer TD, Sargent LA, Burns RP. The evaluation of subatmospheric pressure and hyperbaric oxygen in ischemic full-thickness wound healing. Am Surg 2000; 66 (12): 1136-43.

14. Morykwas MJ, David LR, Schneider AM, Whang C, Jennings DA, Canty C, Parker D, White WL, Argenta LC. Use of subatmospheric pressure to prevent progression of partial-thickness burns in a swine model. J Burn Care Rehabil 1999; 20 (1): 15-21.

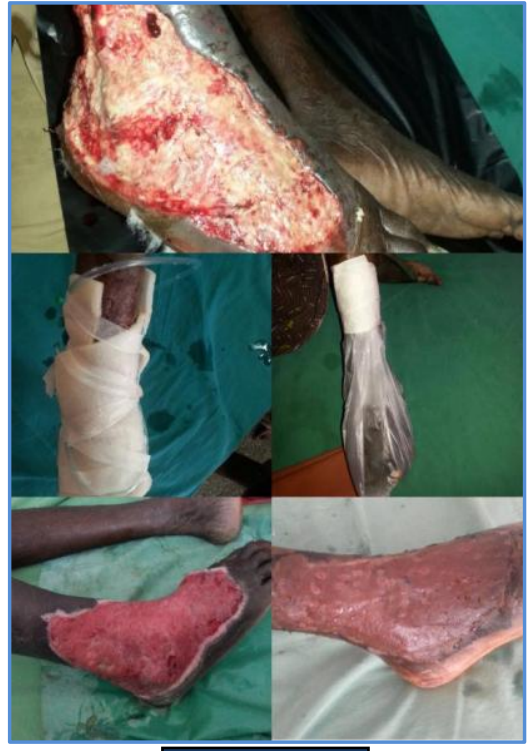

\section{Figure 1}

\section{AUTHORS:}

1. Moganakannan K.

2. Prema M.

3. Arun Sundara Rajan A. R.

\section{PARTICULARS OF CONTRIBUTORS:}

1. Final Year Post Graduate Student, Department of General Surgery, Raja Muthaiah Medical College \& Hospital, Chidambaram.

2. Assistant Professor, Department of General Surgery, Raja Muthaiah Medical College \& Hospital, Chidambaram.
3. First Year Post Graduate Student, Department of General Surgery, Raja Muthaiah Medical College \& Hospital, Chidambaram.

\section{NAME ADDRESS EMAIL ID OF THE CORRESPONDING AUTHOR:}

Dr. Mogankannan, \# 103, Nizam Colony, Pudukkottai.

Email: spartdocarun@gmail.com

Date of Submission: 22/09/2014.

Date of Peer Review: 23/09/2014.

Date of Acceptance: 04/10/2014.

Date of Publishing: 13/10/2014. 